Article

\title{
Antimicrobial Activity and Chemical Constitution of the Crude, Phenolic-Rich Extracts of Hibiscus sabdariffa, Brassica oleracea and Beta vulgaris
}

\author{
Seham Abdel-Shafi ${ }^{1, *(\mathbb{D})}$, Abdul-Raouf Al-Mohammadi ${ }^{2}$, Mahmoud Sitohy ${ }^{3} \mathbb{D}$, Basma Mosa ${ }^{1}$, \\ Ahmed Ismaiel ${ }^{1}$, Gamal Enan ${ }^{1}$ and Ali Osman ${ }^{3}$ (i) \\ 1 Botany and Microbiology Department, Faculty of Science, Zagazig University, Zagazig 44519, Egypt; \\ shefaalab1984@gmail.com (B.M.); ahmedismaiel80@gmail.com (A.I.); gamalenan@ymail.com (G.E.) \\ 2 Department of Science, King Khalid Military Academy, Riyadh 11495, P.O. Box 22140, Saudi Arabia; \\ almohammadi26@hotmail.com \\ 3 Biochemistry Department, Faculty of Agriculture, Zagazig University, Zagazig 44511, Egypt; \\ mzsitohy@hotmail.com (M.S.); ali_khalil2006@yahoo.com (A.O.) \\ * Correspondence: hegazyseham@yahoo.com or sahegazy@zu.edu.eg; Tel.: +20-1289600036
}

Academic Editors: Raffaele Capasso and Lorenzo Di Cesare Mannelli

Received: 12 November 2019; Accepted: 22 November 2019; Published: 24 November 2019

\begin{abstract}
Crude, phenolic-rich extracts (CPREs) were isolated from different sources, such as Hibiscus sabdariffa (H. sabdariffa), Brassica oleracea var. capitata f. rubra (B. oleracea) and Beta vulgaris (B. vulgaris) and characterized. These CPREs showed potential antibacterial and antifungal activities. H. sabdariffa CPRE (HCPRE) is the most potent, as it inhibited all tested bacteria and fungi. Total anthocyanins content (TAC), total phenolic content (TPC) and total flavonoid content (TFC) were estimated in all three CPREs. H. sabdariffa contained $4.2 \mathrm{mg} / 100 \mathrm{~g}$ TAC, $2000 \mathrm{mg} / 100 \mathrm{~g}$ of TPC and $430 \mathrm{mg} / 100 \mathrm{~g}$ of TFC in a dry weight sample. GC-MS analysis of HCPRE showed 10 different active compounds that have antimicrobial effects against pathogenic bacteria and fungi, especially alcoholic compounds, triazine derivatives and esters. Scanning and transmission electron microscopy images of Staphylococcus aureus DSM 1104 and Klebsiella pneumonia ATCC 43816 treated with HCPRE $(50 \mu \mathrm{g} / \mathrm{mL})$ exhibited signs of asymmetric, wrinkled exterior surfaces, cell deformations and loss of cell shapes; and adherence of lysed cell content led to cell clumping, malformations, blisters, cell depressions and diminished cell numbers. This indicates death of bacterial cells and loss of cell contents. Aspergillus ochraceus EMCC516 (A. ochraceus, when treated with $100 \mu \mathrm{g} / \mathrm{mL}$ of HCPRE showed irregular cell organelles and cell vacuolation.
\end{abstract}

Keywords: Hibiscus sabdariffa; Brassica oleracea; Beta vulgaris; crude phenolic rich extract; anthocyanins; GC-MS analysis; antimicrobial

\section{Introduction}

The demand for effective natural antimicrobial compounds free of toxicity and environmental hazards has enormously increased as a result of the mounting increased drug resistant bacteria, nullifying drugs' effectiveness and causing widespread infections [1]. To avoid the increasingly growing antibiotic resistance, many natural products such as native or modified proteins have been investigated for their antibacterial actions as possible substitutes for the antibiotics [2-13]. Pathogenic bacteria and fungi affect agriculture, food industry, consumers and the national economy. The safe, plant-derived compounds with antimicrobial activity against pathogens are vital. For instance, carvacrol and cinnamaldehyde reduced Campylobacter jejuni and Salmonella enterica to undetectable 
levels at $0.2 \%$ concentration. The native cowpea seed proteins $7 S$ and $11 S$ were reported to strongly inhibit the in vitro growth of Pseudomonas aeruginosa ATCC 26853 and Salmonella typhimurium ATCC 14028 [14]. Additionally, soybean's glycinin basic subunit was able to inhibit methicillin-vancomycin intermediate Staphylococcus aureus (MRSA-VISA) while soy glycinin was competent to impede Bacillus spore germination $[15,16]$.

Anthocyanins are the most important group of water-soluble pigments in nature. The word "Anthocyanin" is derived from two Greek words 'anthos' meaning flower and 'kyanos' meaning dark blue, referring to its important role as a natural colorant $[17,18]$. Anthocyanins are the polyphenolics that are responsible for red to purple color in plants. They are members of flavonoid group of phytochemicals $[19,20]$. Primary constituents that are present in flavonoid group are anthocyanins, flavanols, flavones, flavanones, etc. Anthocyanins are the hydroxyl and methoxyl derivatives of phenyl-2-benzopyrylium salts, regarded as flavonoid compounds [21].

The previous study reported two major anthocyanins, delphinidine-3-sambubioside and cyanidine-3-sambubioside, and two minor compounds, i.e., delphinidine-3-glu-coside and cyanidine-3-glucoside, present in the calyces of Hibiscus sabdariffa (roselle) [22]. Approximately 85\% of anthocyanins were delphinidine-3-sambubioside which is the principal source of the antioxidant capacity of roselle extract [23].

The phenolic structure of anthocyanin stands behind their antioxidant activity; i.e., their capability to scavenge reactive oxygen species (ROS); i.e., superoxide $\left(\mathrm{O}_{2}^{-}\right)$, singlet oxygen $\left(\mathrm{O}_{2}\right)$, peroxide (ROO), hydrogen peroxide $\left(\mathrm{H}_{2} \mathrm{O}_{2}\right)$, and hydroxyl radicals $(\mathrm{OH})$ [24]. The herbs' antioxidant activities may be attributed to the plant pigments constituting the major components of the herbal extract. Antioxidant assays in foods and biological systems can be classified in two groups, those based on the evaluation of lipid peroxidation, and those based on the measurement of free radical scavenging power $[25,26]$.

Roselle is widely used for treating diseases. The aqueous methanolic extract of roselle was analyzed for its phytochemical constituents, antimicrobial activity and cytotoxicity, revealing the following components, cardiac glycosides, flavonoids, saponins and alkaloids. It exhibited in vitro antibacterial activities against Staphylococcus aureus, Bacillus stearothermophilus, Micrococcus luteus, Serratia mascences, Clostridium sporogenes, Escherichia coli, Klebsiella pneumoniae, Bacillus cereus and Pseudomonas fluorescence [27].

The in vitro antimicrobial action of roselle extract was ascribed to the flavonoids, which can establish complexes with the bacterial cell walls, enhancing their permeation to the extract. The mechanism of action may include some metabolic steps, e.g., inhibition of electron transport protein translocation, phosphorylation steps, and some other enzyme dependent reactions ending with raised membrane permeability coupled with the leakage of the bacterial cell constituents [28].

Red cabbage (Brassica oleracea L.) has been extensively studied, due to its distinct color and potential physiological functions, arising probably from the presence of anthocyanin [29], the major pigment of this plant [30], which is composed of cyanidin-3-diglucoside-5-glucoside "cores," that are non-acetylated, mono-acetylated or di-acetylated with p-coumaric, caffeic, ferulic and sinapic acids. Anthocyanin was previously extracted from red cabbage using high pressure $\mathrm{CO}_{2}$ [31]. Red cabbage is one of the most important vegetables belonging to the family Cruciferae. It is an herbaceous plant characterized by a short stem crowned up with a mass of red leaves (head). It is mainly used as salad, but can be cooked or pickled. Red cabbage is known for its medicinal properties; e.g., anticancer activity, due to the presence of indole-3-carbinol. It is an excellent source of vitamin C, vitamin B complex, potassium and calcium. The purple/red color leaves are due to a pigment belonging to anthocyanins (flavins). This color varies according to the soil $\mathrm{pH}$, being more reddish in acidic soils, purple in neutral soils and greenish yellow in alkaline soil. Red cabbage is a rich source of natural antioxidants such as ascorbic acid, $\alpha$-tocopherol, $\beta$-carotene and lutein [32]; oligosaccharides; and a some bioactive substances; e.g., flavonols and glucosinolates [33]. Its wide spread use in traditional medicine were ascribed to its antioxidant, anti-inflammatory and antibacterial properties. It is used 
for treating symptoms associated with gastrointestinal disorders; e.g., peptic and duodenal ulcers, gastritis or irritable bowel syndrome [34].

Natural colorants may be promising active biological agents. For example, phycocyanins were found to have many biological activities [35-37]. Likewise, red beet (Beta vulgaris L.) grows red or purple tuberous root vegetables, known as beetroot or garden beets, which are a firm, clean, globe-shaped vegetable with no mucilaginous or watery tissues, and its tubers contain freshly emerged young leaves. The biological importance of red beet is based on its high red pigment content, (betalain), which displays excellent values, meeting some applications in food and pharmaceutical products. Among many plants accumulating betalains, only red beet and prickly pear (Opuntia ficus-indica) are approved for food and pharmaceutical applications [38]. For example, the use of beet extract as a food colorant is approved by the US Food and Drug Administration (FDA). As a powerful antioxidant pigment, betanin may provide protection and reduce risk of cardiovascular disease and cancer [39].

Based on the potentially high content of anthocyanins and other bioactive compounds, three plants growing in Egypt were selected for this study; Hibiscus sabdariffa (H. sabdariffa), Brassica oleracea (B. oleracea) and Beta vulgaris (B. vulgaris), as the sources for isolating the crude phenolic rich extract (CPRE). These extracts (CPRE) were analyzed for total phenolics content and total flavonoids and evaluated for their antibacterial and antifungal activity by different methods.

\section{Results}

\subsection{Chemical Characterization of Isolated CPRE}

\subsubsection{Total Anthocyanin, Total Phenolic and Total Flavonoid Contents}

Total phenolic contents (TPC) of all samples were assayed by Folin-Ciocalteu's method, and found to be varied (Table 1). The highest amount of TPC was observed in H. sabdariffa CPRE (HCPRE) (2000 mg GAE/100 g dry pigment). B. oleracea showed the lowest amount of TPC (150 mg GAE/100 g dry pigment). The highest amounts of anthocyanin and flavonoid contents were observed with HCPRE.

Table 1. Chemical characterization of isolated pigments.

\begin{tabular}{cccc}
\hline Samples & $\begin{array}{c}\text { Total Anthocyanin Content } \\
\text { (mg/100 g Dry Pigment) }\end{array}$ & $\begin{array}{c}\text { Total Phenolic Content (mg } \\
\text { GAE/100 g Dry Pigment) }\end{array}$ & $\begin{array}{c}\text { Total Flavonoid Content (mg } \\
\text { QE/100 g Dry Pigment) }\end{array}$ \\
\hline H. sabdariffa & 4.2 & 2000 & 430 \\
B. oleracea & 2.7 & 150 & 50 \\
B. vulgaris & 3.8 & 400 & 120 \\
\hline
\end{tabular}

GAE: gallic acid equivalent. QE: quercetin equivalent.

\subsubsection{Gas Chromatography-Mass Spectrometry (GC-MS) Analysis of HCPRE}

The chemical compounds extracted from HCPRE $(2000 \mu \mathrm{g} / \mathrm{mL})$ were obtained by GC-MS analysis (Table 2; Figure 1). HCPRE contains ten active compounds, most of which have antimicrobial effects against pathogenic bacteria and fungi, especially alcoholic compounds, triazine derivatives, mercepto compounds and esters. 
Table 2. The chemical compounds in the Hibiscus sabdariffa pigment (crude, phenolic-rich extracts-HCPRE) extracted, analyzed by GC-MS.

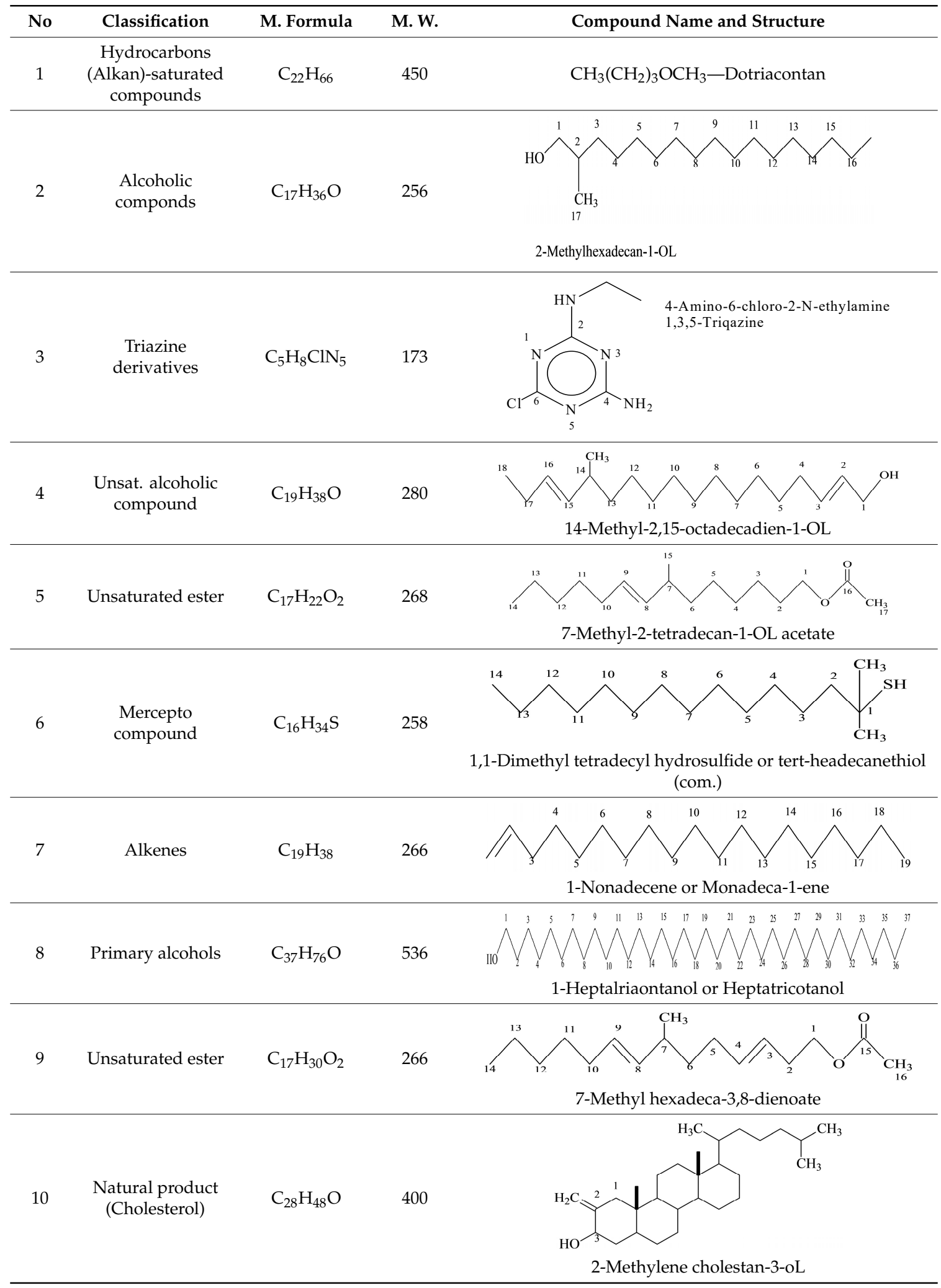




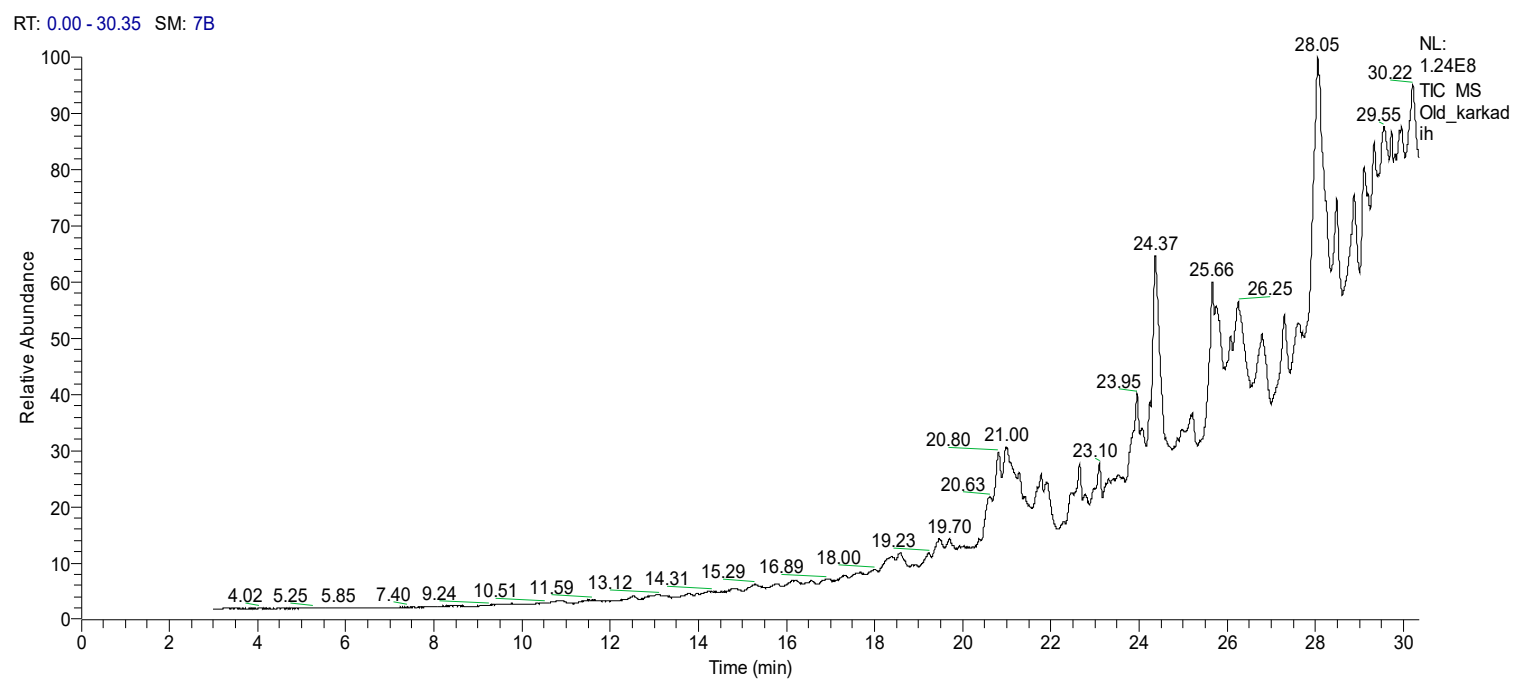

Figure 1. The TIC chromatogram of H. sabdariffa using GC-MS. RT—retention Time; SM-signal in method; NL-noise level.

\subsection{Antimicrobial Activity of Crude Phenolic Rich Extract (CPRE) (2000 $\mu \mathrm{g} / \mathrm{mL})$ against Pathogenic Bacteria}

The CPREs from $\mathrm{H}$. sabdariffa, Brassica oleracea var. capitata f. rubra and B. vulgaris $(2000 \mu \mathrm{g} / \mathrm{mL})$ were tested for their antibacterial actions against S. aureus, Streptococcus pyogenes, Listeria monocytogenes, E. coli, K. pneumonia and Pseudomonas aeruginosa (Table 3). HCPRE exhibited the highest inhibition zones against the all bacteria, but B. vulgaris pigment had lower inhibition zones.

Table 3. Antibacterial activity of crude phenolic rich extracts (CPREs) $(2000 \mu \mathrm{g} / \mathrm{mL})$ from three plants against pathogenic bacteria using agar well diffusion assays.

\begin{tabular}{cccc}
\hline \multirow{2}{*}{ Microorganisms } & \multicolumn{3}{c}{ Inhibition Zone (mm) } \\
\cline { 2 - 4 } & H. sabdariffa & B. oleracea & B. vulgaris \\
\hline Gram positive bacteria & $48 \pm 8.0^{\mathrm{b}}$ & $38 \pm 3.0^{\mathrm{a}}$ & $24 \pm 4.0^{\mathrm{a}}$ \\
S. aureus & $40 \pm 5.0^{\mathrm{b}}$ & $32 \pm 2.0^{\mathrm{b}}$ & $10 \pm 2.0^{\mathrm{b}}$ \\
St. pyogenes & $32 \pm 4.0^{\mathrm{c}}$ & $37 \pm 3.0^{\mathrm{a}}$ & $13 \pm 3.0^{\mathrm{b}}$ \\
L. monocytogenes & $46 \pm 6.0^{\mathrm{a}}$ & $28 \pm 0.50^{\mathrm{c}}$ & $7 \pm 0.50^{\mathrm{c}}$ \\
Gram negative bacteria & $48 \pm 6.5^{\mathrm{a}}$ & $30 \pm 2.0^{\mathrm{b}}$ & $18 \pm 2.0^{\mathrm{a}}$ \\
E. coli & $32 \pm 3.0^{\mathrm{c}}$ & $29 \pm 0.50^{\mathrm{c}}$ & $7 \pm 0.50^{\mathrm{c}}$ \\
K. pneumonia & . aeruginosa &
\end{tabular}

Means in the same column having different letters are significantly different $(p \leq 0.05)$.

\subsection{Minimum Inhibitory Concentrations (MICs) Values of HCPRE and B. oleracea Pigments against Bacteria}

Different concentrations of extracted HCPRE were prepared $(0,25,50,100,200$ and $250 \mu \mathrm{g} / \mathrm{mL})$ and tested for their antibacterial action (Table 4, Figure S1). The results indicated that the MIC of the pigment against Gram positive S. aureus, S. pyogenes and L. monocytogenes was $50 \mu \mathrm{g} / \mathrm{mL}$; the MIC against Gram negative E. coli and P. aeruginosa was $25 \mu \mathrm{g} / \mathrm{mL}$; and it was $50 \mu \mathrm{g} / \mathrm{mL}$ for K. pneumoniae. S. aureus and K. penuomonia are the most sensitive bacteria to HCPRE. Different concentrations of extracted B. oleracea pigment (BOP) were prepared $(0,25,50,100,200$ and $250 \mu \mathrm{g} / \mathrm{mL}$ ) and tested for their antibacterial action against pathogenic bacteria (Table 4). The results showed that the MICs of the BOP against S. aureus, S. pyogenes and L. monocytogens were 25,100 and $50 \mu \mathrm{g} / \mathrm{mL}$; and against E. coli, K. pneumonia and P. aeruginosa were 100, 200 and $100 \mu \mathrm{g} / \mathrm{mL}$ respectively. S. aureus and P. aeruginosa are the most sensitive bacteria to BOP. 
Table 4. Minimum Inhibitory Concentrations (MIC) values of HCPRE and Brassica oleracea pigments against pathogenic bacteria using agar well diffusion assays.

\begin{tabular}{|c|c|c|c|c|c|c|}
\hline \multirow{2}{*}{ Microorganisms } & \multicolumn{6}{|c|}{ Inhibition Zone (mm) } \\
\hline & $\mathbf{0}$ & 25 & 50 & 100 & 200 & 250 \\
\hline \multicolumn{7}{|c|}{ H. sabdariffa pigment } \\
\hline \multicolumn{7}{|l|}{ Gram positive bacteria } \\
\hline S. aureus & - ve & - ve & $15 \pm 3.0^{c}$ & $20 \pm 2.0^{b}$ & $23 \pm 3.0^{b}$ & $28 \pm 4.0^{\mathrm{a}}$ \\
\hline St. pyogenes & -ve & - ve & $9 \pm 0.5^{c}$ & $15 \pm 1.0^{\mathrm{b}}$ & $20 \pm 2.0^{a}$ & $22 \pm 2.0^{\mathrm{a}}$ \\
\hline L. monocytogenes & - ve & - ve & $11 \pm 1.5^{\mathrm{c}}$ & $22 \pm 3.0^{b}$ & $23 \pm 3.0^{b}$ & $26 \pm 3.0^{a}$ \\
\hline \multicolumn{7}{|c|}{ Gram negative bacteria } \\
\hline E. coli & - ve & $11 \pm 1.5^{\mathrm{c}}$ & $14 \pm 2.0^{\mathrm{c}}$ & $20 \pm 2.0^{b}$ & $24 \pm 4.0^{b}$ & $30 \pm 5.0^{\mathrm{a}}$ \\
\hline K. pneumonia & - ve & -ve & $15 \pm 3.0^{\mathrm{c}}$ & $20 \pm 2.0^{b}$ & $25 \pm 5.0^{a}$ & $26 \pm 3.0^{\mathrm{a}}$ \\
\hline P. aeruginosa & - ve & $10 \pm 1.0$ & $14 \pm 2.0$ & $23 \pm 3.0$ & $29 \pm 6.0$ & $30 \pm 4.0$ \\
\hline \multicolumn{7}{|c|}{ B. oleracea pigment } \\
\hline \multicolumn{7}{|l|}{ Gram positive bacteria } \\
\hline S. aureus & - ve & $9 \pm 1.0^{\mathrm{c}}$ & $12 \pm 2.0^{\mathrm{c}}$ & $16 \pm 2.0^{b}$ & $21 \pm 2.0^{\mathrm{a}}$ & $25 \pm 3.0^{\mathrm{a}}$ \\
\hline St. pyogenes & $-\mathrm{ve}$ & - ve & - ve & $9 \pm 0.5^{b}$ & $10 \pm 1.0^{\mathrm{a}}$ & $11 \pm 1.0^{\mathrm{a}}$ \\
\hline L. monocytogenes & - ve & - ve & $9 \pm 1.0^{\mathrm{c}}$ & $12 \pm 1.5^{\mathrm{c}}$ & $23 \pm 3.0^{b}$ & $26 \pm 4.0^{\mathrm{a}}$ \\
\hline \multicolumn{7}{|c|}{ Gram negative bacteria } \\
\hline E. coli & - ve & - ve & - ve & $10 \pm 1.0^{b}$ & $16 \pm 2.0^{a}$ & $17 \pm 2.0^{\mathrm{a}}$ \\
\hline K. pneumonia & $-\mathrm{ve}$ & - ve & - ve & - ve & $11 \pm 1.0^{b}$ & $13 \pm 1.5^{\mathrm{a}}$ \\
\hline P. aeruginosa & - ve & - ve & - ve & $11 \pm 1.2^{\mathrm{c}}$ & $15 \pm 2.0^{b}$ & $19 \pm 2.5^{\mathrm{a}}$ \\
\hline
\end{tabular}

Means in the same row having different letters are significantly different $(p \leq 0.05)$.

\subsection{Antifungal Activity of HCPRE against Pathogenic Fungi and MIC Values}

HCPRE $(2000 \mu \mathrm{g} / \mathrm{mL})$ strongly inhibited all tested fungi (Table 5). Different concentrations of HCPRE extract were prepared $(0,100,200,300,400$ and $500 \mu \mathrm{g} / \mathrm{mL})$ and tested for their antifungal actions against pathogenic fungi. The results showed that the MICs of the pigment against the fungi (A. ochraceus, F. oxysporum, P. expansum and P. citrinum) were $100 \mu \mathrm{g} / \mathrm{mL}$, and according to the diameter of inhibition zones it showed that A. ochraceus was the most sensitive fungus to HCPRE (Table 6; Figure S2). Moreover, different concentrations of extracted B. oleracea pigment were prepared $(0,100$, $200,300,400$ and $500 \mu \mathrm{g} / \mathrm{mL}$ ) and tested for their antifungal actions against pathogenic fungi.

Table 5. Antifungal activities of some plant pigments $(2000 \mu \mathrm{g} / \mathrm{mL})$ against pathogenic fungi using well diffusion assays.

\begin{tabular}{cccc}
\hline \multirow{2}{*}{ Microorganismis } & \multicolumn{3}{c}{ Inhibition Zone (mm) } \\
\cline { 2 - 4 } & H. sabdariffa & B. oleracea & B. vulgaris \\
\hline A. ochraceus & $45 \pm 5.0^{\mathrm{a}}$ & $20 \pm 2.0^{\mathrm{b}}$ & $-\mathrm{ve}$ \\
F. oxysporum & $40 \pm 4.0^{\mathrm{b}}$ & $22 \pm 3.0^{\mathrm{a}}$ & $-\mathrm{ve}$ \\
P. expansum & $35 \pm 3.0^{\mathrm{c}}$ & $-\mathrm{ve}$ & $-\mathrm{ve}$ \\
P. citrinum & $36 \pm 3.2^{\mathrm{c}}$ & $-\mathrm{ve}$ & $-\mathrm{ve}$
\end{tabular}

Means in the same column having different letters are significantly different $(p \leq 0.05)$. -ve: No inhibition zone.

The results showed that the MICs of BOP against A. ochraceus and F. oxysporum were 400 and $300 \mu \mathrm{g} / \mathrm{mL}$, respectively. BOP do not inhibit the growth of P. expansum and P. citrinum (Table 6, Figure S2). 
Table 6. MICs of H. sabdariffa and B. oleracea pigments against pathogenic fungi using well diffusion assay.

\begin{tabular}{ccccccc}
\hline \multirow{2}{*}{ Microorganisms } & \multicolumn{7}{c}{ Inhibition Zone (mm) } \\
\cline { 2 - 7 } & $\mathbf{0}$ & $\mathbf{1 0 0}$ & $\mathbf{2 0 0}$ & $\mathbf{3 0 0}$ & $\mathbf{4 0 0}$ & $\mathbf{5 0 0}$ \\
\hline & \multicolumn{7}{c}{ H. sabdariffa pigment } \\
A. ochraceus & $-\mathrm{ve}$ & $23 \pm 2.0^{\mathrm{c}}$ & $30 \pm 3.0^{\mathrm{bc}}$ & $34 \pm 3.0^{\mathrm{b}}$ & $35 \pm 3.0^{\mathrm{b}}$ & $40 \pm 5.0^{\mathrm{a}}$ \\
F. oxysporum & $-\mathrm{ve}$ & $12 \pm 1.0^{\mathrm{d}}$ & $15 \pm 1.5^{\mathrm{c}}$ & $20 \pm 2.0^{\mathrm{b}}$ & $25 \pm 2.0^{\mathrm{a}}$ & $26 \pm 2.0^{\mathrm{a}}$ \\
P. expansum & $-\mathrm{ve}$ & $9 \pm 0.5^{\mathrm{c}}$ & $20 \pm 2^{\mathrm{b}}$ & $21 \pm 2.0^{\mathrm{b}}$ & $28 \pm 2.5^{\mathrm{a}}$ & $32 \pm 3.0^{\mathrm{a}}$ \\
P. citrinum & $-\mathrm{ve}$ & $13 \pm 1.5^{\mathrm{d}}$ & $25 \pm 3.0^{\mathrm{c}}$ & $32 \pm 3.0^{\mathrm{b}}$ & $33 \pm 3.0^{\mathrm{b}}$ & $38 \pm 4.0^{\mathrm{a}}$ \\
& \multicolumn{7}{c}{ B. oleracea pigment } & & & \\
A. ochraceus & $-\mathrm{ve}$ & $-\mathrm{ve}$ & $-\mathrm{ve}$ & $-\mathrm{ve}$ & $13 \pm 2.0^{\mathrm{b}}$ & $15 \pm 1.0^{\mathrm{a}}$ \\
F. oxysporum & $-\mathrm{ve}$ & $-\mathrm{ve}$ & $-\mathrm{ve}$ & $9 \pm 1.0^{\mathrm{c}}$ & $11 \pm 1.0^{\mathrm{b}}$ & $18 \pm 2.0^{\mathrm{a}}$ \\
P. expansum & $-\mathrm{ve}$ & $-\mathrm{ve}$ & $-\mathrm{ve}$ & $-\mathrm{ve}$ & $-\mathrm{ve}$ & $-\mathrm{ve}$ \\
P. citrinum & $-\mathrm{ve}$ & $-\mathrm{ve}$ & $-\mathrm{ve}$ & $-\mathrm{ve}$ & $-\mathrm{ve}$ & $-\mathrm{ve}$ \\
\hline
\end{tabular}

-ve: No inhibition zone. Mean in the same row having different letters are significantly different $(p \leq 0.05)$.

\subsection{Quantitative Inhibition of Pathogenic Bacteria by Plant Pigments (Bacterial Growth Curve)}

Plant pigments ( $H$. sabdariffa and B. oleraceae) were added at their MIC values to test tubes containing $10 \mathrm{~mL} \mathrm{NB}$ and inoculated with $10 \mu \mathrm{l}$ aliquots of bacterial suspensions. Samples and untreated test tubes (controls) were incubated at $37^{\circ} \mathrm{C}$ for $30 \mathrm{~h}$. At appropriate time intervals, $1 \mathrm{~mL}$ aliquots of bacterial suspensions were withdrawn and were analyzed for their turbidity at OD600. Results are given in (Figure 2).

In the case of treating with $H$. sabdariffa pigment, almost no growth was shown in bacterial test tubes treated with pigment. However, bacteria grew rapidly in control tubes (without pigment) and turbidity went from 0.1 to almost 1.2 at OD600. Distinctive inhibition was observed at OD600, which increased only $\geq 0.0$ in all of them. Moderate inhibition was observed for growth recorded at OD600 within $30 \mathrm{~h}$ in contradicting situations. In case of BOP bacteria grew rapidly in control tubes and bacterial growth inhibited in treated tubes. 

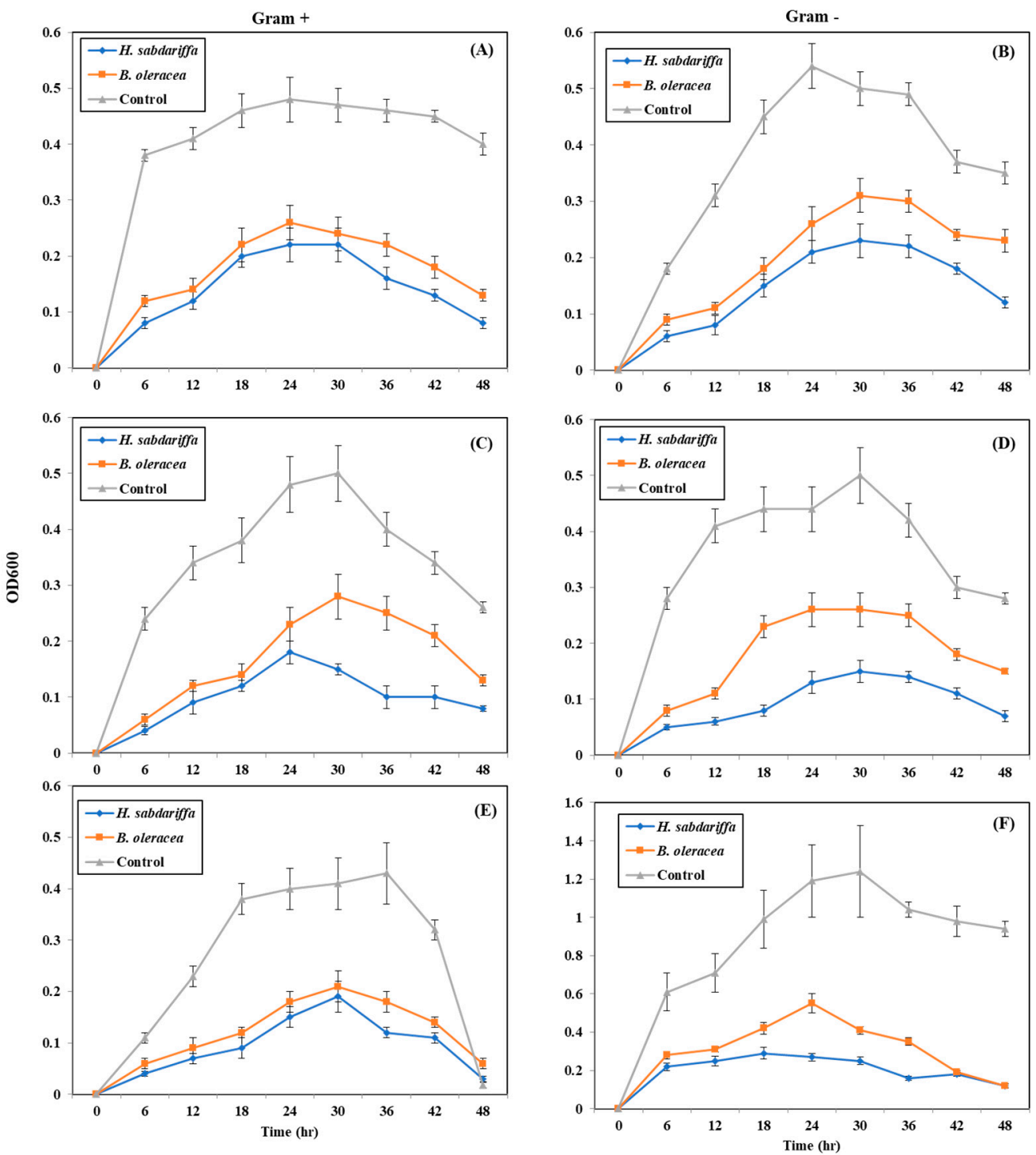

Figure 2. Quantitative inhibition of Gram-positive and Gram-negative bacteria by MIC of $H$. sabdariffa crude phenolic rich extract. (A) S. aureus; (B) E. coli; (C) St. pyogenes; (D) K. pneumonia; (E) L. monocytogenes; (F) P. aeruginosa.

\subsection{SEM and TEM Microscopy Analysis}

SEM images showed that the presence of HCPRE $(50 \mu \mathrm{g} / \mathrm{mL})$ on NB media containing S. aureus affected the bacterial cells and caused cell deformations, wrinkles and loss of cell shapes. The adherence of lysed cell content led to cell clumping, and this was seen after $18 \mathrm{~h}$ of incubation at $37^{\circ} \mathrm{C}$. HCPRE $(50 \mu \mathrm{g} / \mathrm{mL})$ on nutrient broth (NB) media containing K. pneumonia showed malformations (increases in length and decrease in width), cell depressions, diminished cell number and observed rectangular cells as loss of regular cell shapes were detected. That indicates the death of cells and loss of cellular contents. SEM images of A. ochraceus treated with HCPRE $(100 \mu \mathrm{g} / \mathrm{mL})$ showed destruction of conidia, failing in conidia formation, thinning and condensation of mycelia; then, malformation and loss of cell contents.

TEM images showed that $S$. aureus and K. pneumonia affected by HCPRE $(50 \mu \mathrm{g} / \mathrm{mL})$ on NB media showed malformed shapes, cell depress, cell vacuolation, blisters and wrinkles.

A. ochraceus, when treated with $(100 \mu \mathrm{g} / \mathrm{mL})$ of HCPRE showed irregular cell organelles and cell vacuolation (Figure $3 \mathrm{~A}-\mathrm{F}$ ). 
S. aureus (control)

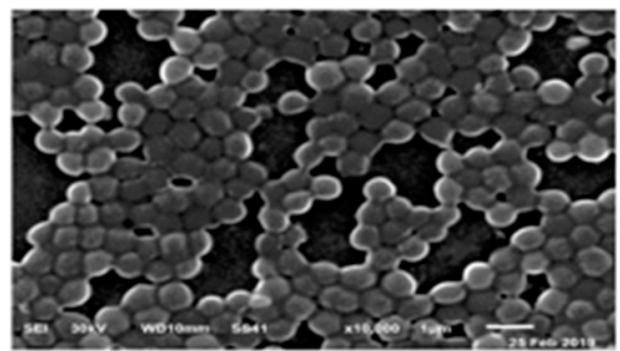

S. aureus (control)

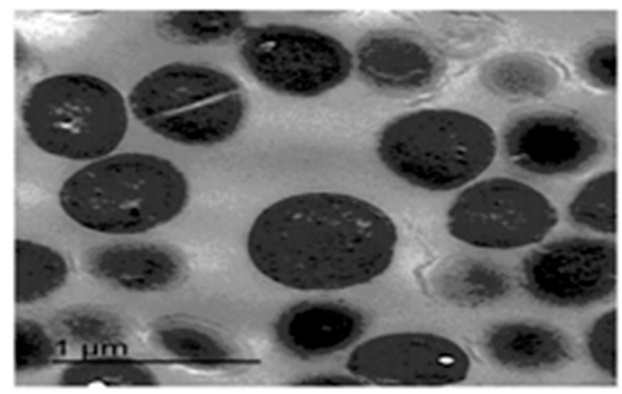

K. pneumonia (control)

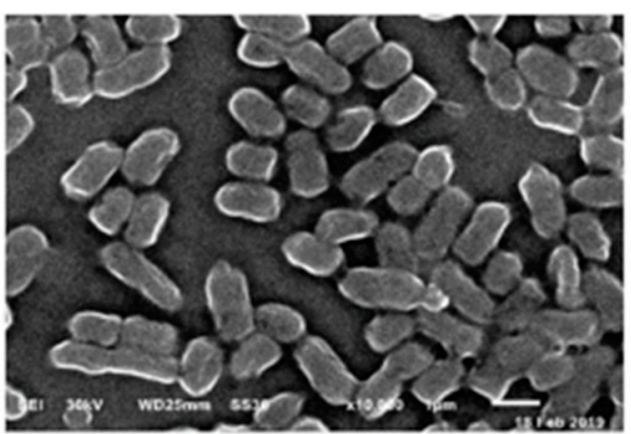

K. pneumonia (control)

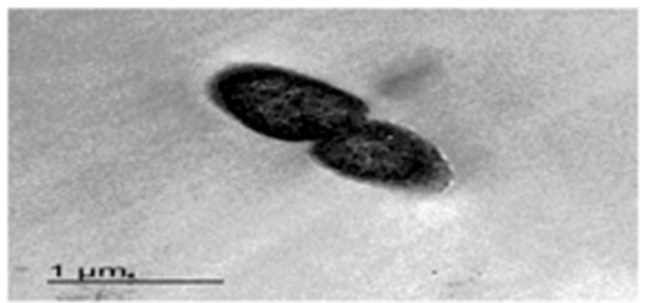

S. aureus (treated)

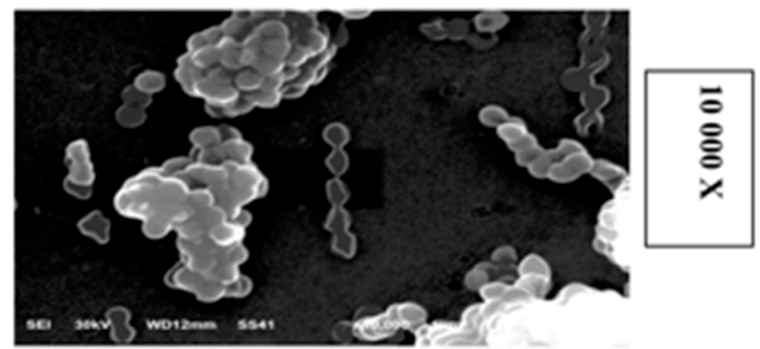

(A)

S. aureus (treated)

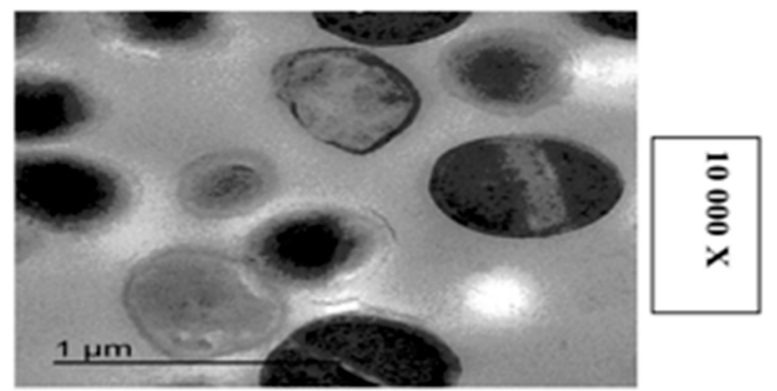

(B)

K. pneumonia (treated)

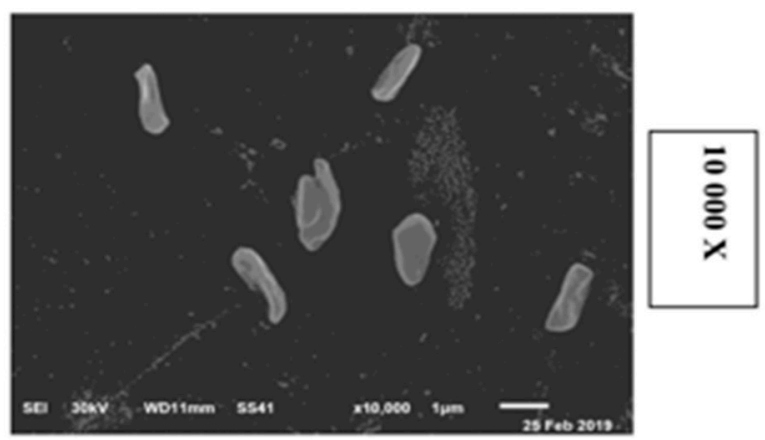

(C)

K. pneumonia (treated)

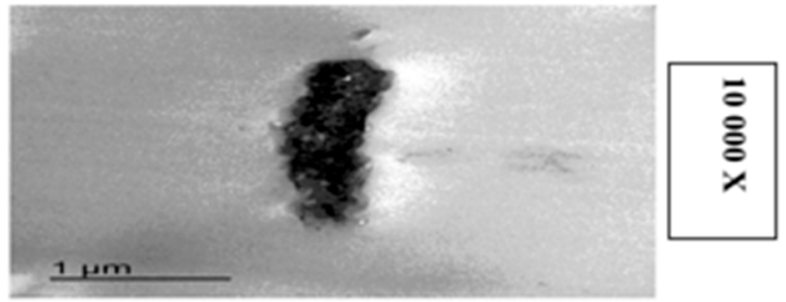

(D)

Figure 3. Cont. 

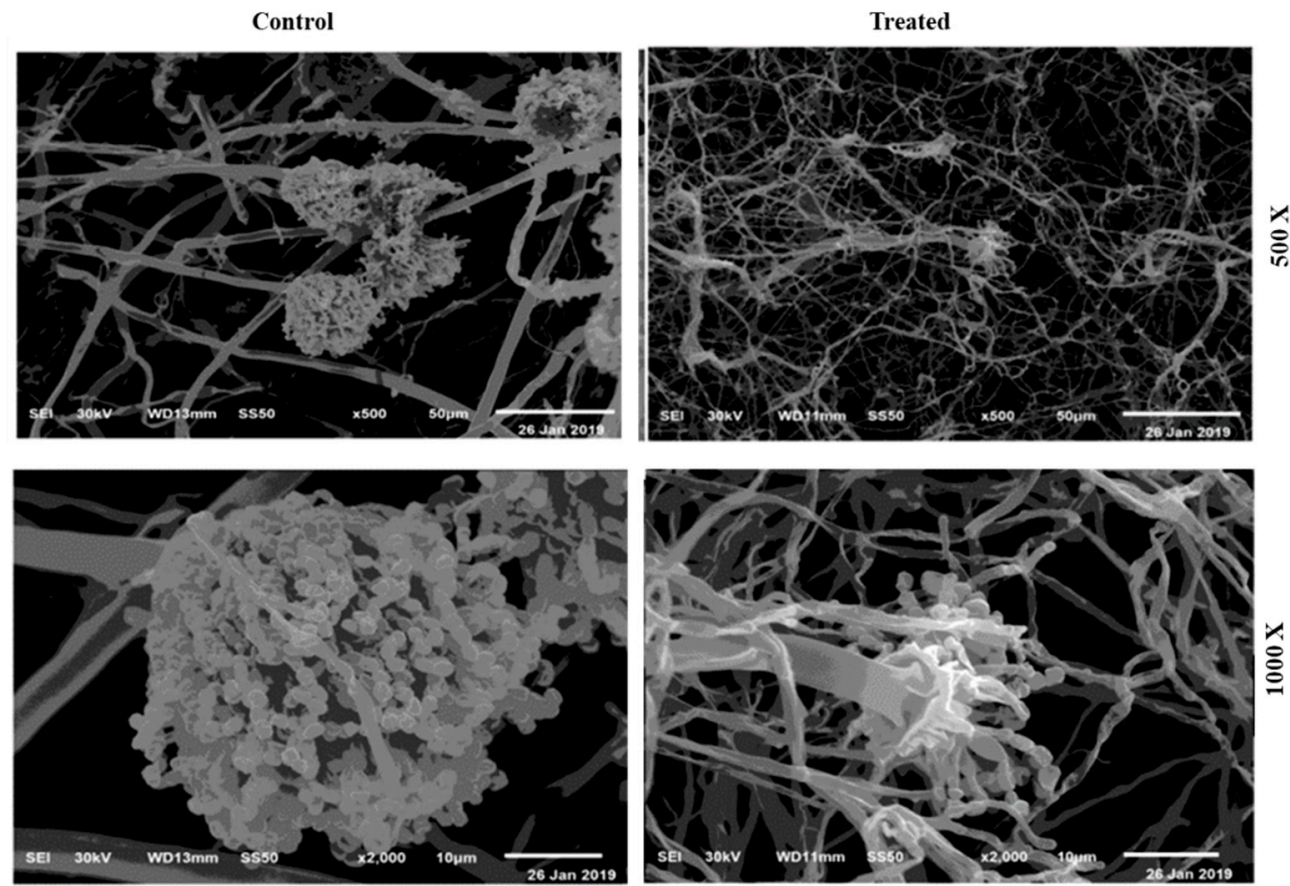

(E)

control)

treated)
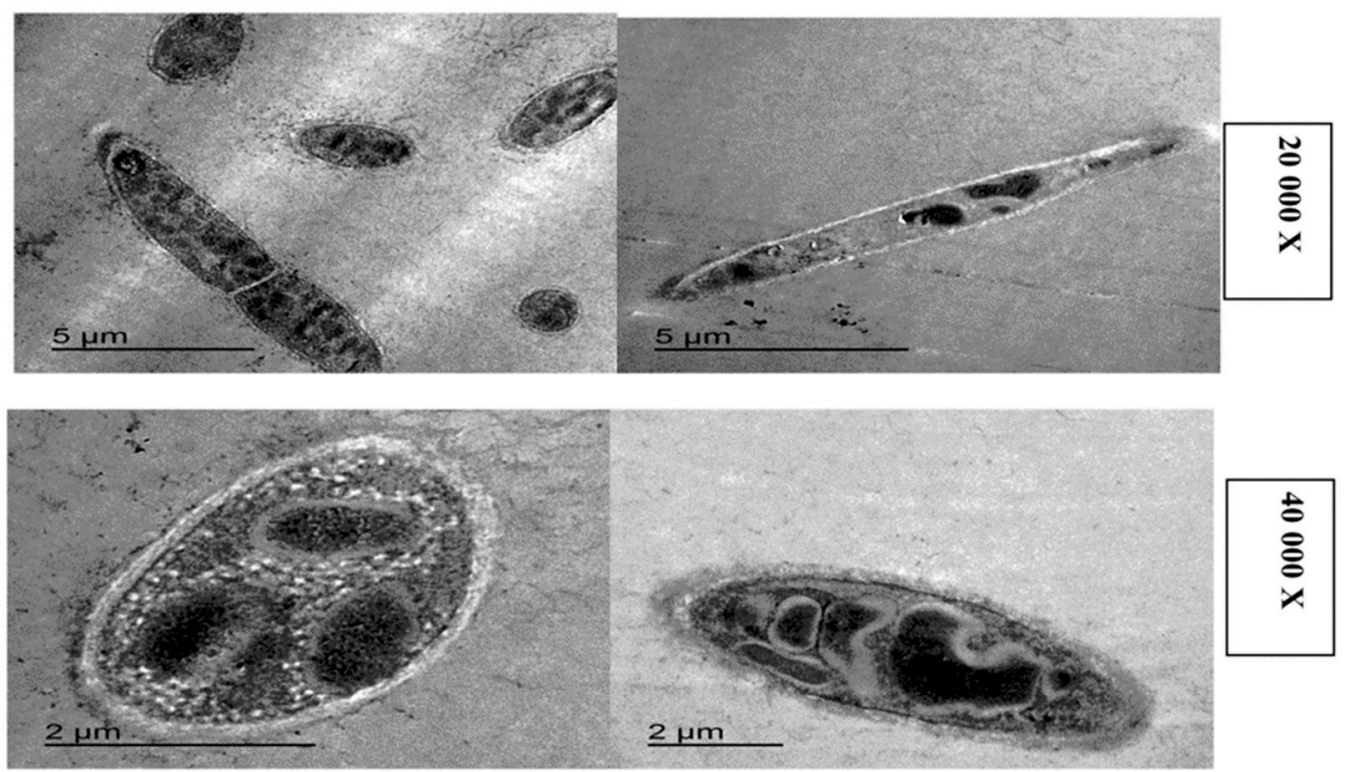

(F)

Figure 3. (A) SEM of Staphylococcus aureus affected by $50 \mu \mathrm{g} / \mathrm{mL}$ of HCPRE. (B) TEM of S. aureus affected by $50 \mu \mathrm{g} / \mathrm{mL}$ of HCPRE. (C) SEM of K. pneumonia affected by $50 \mu \mathrm{g} / \mathrm{mL}$ of HCPRE. (D) TEM of K. pneumonia affected by $50 \mu \mathrm{g} / \mathrm{mL}$ of HCPRE. (E) SEM of $A$. ochraceus affected by $100 \mu \mathrm{g} / \mathrm{mL}$ of HCPRE. (F) TEM of $A$. ochraceus affected by $100 \mu \mathrm{g} / \mathrm{mL}$ of HCPRE.

\section{Discussion}

Natural colorants obtained from vegetables are more available and healthy than synthetic colors [40]. The natural pigments are used in medicine and food [41]. Many bacterial organisms have developed increasing resistance against the frequently used antibiotics [42]. 
In this study, the pigments extracted from $H$. sabdariffa inhibited all tested bacteria and fungi. The previous studies showed that H. sabdariffa inhibited S. aureus, B. cereus, E. coli, Clostridium sp., Klebsiella pneumonia and Pseudomonas fluorescens [42]. Herbal drug formulations composed of medicinal plants have been inherited from ancient times to treat many diseases, since their antimicrobial properties suggest them as potentially rich sources of various potent drugs [43]. Natural antimicrobials have enormous therapeutic potential, since they can probably conduct the required functions without any posing health hazards often associated with synthetic agents [44]. H. sabdariffa's aqueous extract has strong activity against C. albicans [27]. Roselle can be utilized either as a distinct functional food or as an active ingredient in other functional food potentially applicable in the treatment of various degenerative diseases [45].

Based on the results, the antibacterial action of anthocyanin was concentration-dependent. HCPRE contains total anthocyanin content of $4.2(\mathrm{mg} / 100 \mathrm{~g})$ in dry pigment. Anthocyanin had relatively higher antibacterial activity than antifungal activity against the microorganisms investigated. Anthocyanins were reported to have anticarcinogenic activity against multiple cancer cell lines in vitro and in vivo tumor types [46]. H. sabdariffa showed antimicrobial activities against some food pathogenic microbial isolates, e.g., E. coli O157:H7, Salmonella enterica and L. monocytogenes, as well as veterinary, and clinical isolates. This indicated that HCPRE extract is broadly effective against different microorganisms, suggesting its application as a potential food-grade antimicrobial [28]. The antibacterial effects of roselle calyx aqueous and ethanol extracts and protocatechuic acid against food spoilage bacteria Salmonella typhimurium DT104, E. coli O157:H7, L. monocytogenes, S. aureus and B. cereus were examined by [47]. The inhibitory activities in a dose-dependent manner against bacteria in ground beef and apple juice were studied, and it was suggested that they might be potent agents as food additives to prevent contamination from these bacteria.

The anthocyanins and polyphenols from the H. sabdariffa (roselle) were extracted by an aqueous or organic solvent. The dried roselle contained total anthocyanins as cyanidine 3-glucoside $622.91 \mathrm{mg} / 100 \mathrm{~g}$ and $37.42 \mathrm{mg} / 100 \mathrm{~g}$ total phenolic content in dry weight samples [48]. A recent study identified delphinedine-3-O-sambubioside, delphinidine-3-O-glucoside and cyani-dine-3-O-sambubioside at the concentrations of $7.03 \mathrm{mg} / \mathrm{g}, 1.54 \mathrm{mg} / \mathrm{g}$ and $4.40 \mathrm{mg} / \mathrm{g}$ in the roselle extract. GC-MS analysis showed 10 compounds in HCPRE. All of them have previously been shown to have antimicrobial activity. It is quite known that many Hibiscus species contain different classes of secondary metabolites, including flavonoids, anthocyanins, terpenoids, steroids, polysaccharides, alkaloids, sesquiterpene, quinones and naphthalene groups. Some of these components have antibacterial, anti-inflammatory, antihypertensive, antifertility, hypoglycemic, antifungal and antioxidative activities [49]. The antioxidant capacity of anthocyanins is dependent on its basic structural orientation; i.e., the ring orientation will determine the readiness of a hydrogen atom from a hydroxyl group to be donated to a free radical and the capability of the anthocyanin to support an unpaired electron [25]. H. sabdariffa is a safe medicinal plant, having medical compounds with nutritional and medicinal properties [50].

In this study, S. aureus and K. pneumonia were affected by HCPRE (50 $\mu \mathrm{g} / \mathrm{mL})$, showing malformed shapes, cell depressions, cell vacuolation, blisters and wrinkles. A. ochraceus, when treated with $(100 \mu \mathrm{g} / \mathrm{mL})$ of HCPRE, showed irregular cell organelles. The anthocyanin-rich blueberry extract was capable of inhibiting the growth, adhesion and/or biofilm formation of all of the following: P. aeruginosa, E. coli, P. mirabilis, A. baumannii and S. aureus [51]. Roselle contains proanthocyanidins which combine or transform the structural entity of P-fimbriae of bacterial cells; thus, inhibiting their adhesion to the ur-epithelium and formation of biofilms in vitro [45]. The antimicrobial properties of eight food dyes against 10 bacteria and five fungal organisms were previously investigated, showing that the red dyes were associated with the best antibacterial activities, while the yellow ones were more linked to better antifungal activity. Besides the antimicrobial analysis, antioxidant activity, measured by three different methods, was also investigated. In all the methods, red dye was found to have greater antioxidant activity. It suggests that the addition of these dyes in food not only enhances the value addition by making the food more presentable but also shall address the issue of food 
supplementation with substances that are good antibiotics and antioxidants, subsequently proving to be health benefactors [52].

\section{Materials and Methods}

\subsection{Crude Phenolic Rich Extract (CPRE) Preparation}

All chemicals used in this work were supplied from Al-Gomhorya Company for chemicals and public procurement Zagazig city, Egypt. The calyx of $H$. sabdariffa; the leaves of Brassica oleracea var. capitata f. rubra (B. oleracea) and B. vulgaris tuberous root vegetables were obtained from local market in Egypt). The plants we used were botanically classified by Samer Teleb, Taxonomy and Flora, Botany and Microbiology Department, Faculty of Science, Zagazig University, Egypt. Milled sample (0.5 g) was soaked in $50 \mathrm{~mL}$ of ethanol for $24 \mathrm{~h}$ and the extract obtained was pre-filtered with Whatman No.4 filter (Whatman®Prepleated Qualitative Filter Paper, Grade 4V, Sigma-Aldrich, USA) before evaporation using a vacuum rotary evaporator (BüCHI-water bath-B-480, Czech Republic) at $30^{\circ} \mathrm{C}$.

\subsection{Crude Phenolic Rich Extract Characterization}

\subsubsection{Determination of Anthocyanins}

Total anthocyanin content was colorimetrically determined according to the procedure described by [53] where a known volume of the filtered extract was diluted to $100 \mathrm{~mL}$ with the extracting solvent and the resulting color was measured at $520 \mathrm{~nm}$ for water and citric acid solution extracts and at $535 \mathrm{~nm}$ for acidified ethanol using Spectrophotometer (JENWAY-6405 UV/VIS, Chelmsford, England). The total anthocyanin content defined as cyanidin-3-glucoside was calculated using the following Equation (1):

$$
\text { Total anthocyanins }\left(\frac{\mathrm{mg}}{100 \mathrm{~g}}\right)=\frac{\text { Absorbance } \times \text { dilution factor }}{\text { Sample weight } \times 55.9} \times 100 \text {. }
$$

\subsubsection{Determination of Total Phenolic Compounds (TPCs)}

The TPCs were estimated by Foline-Ciocalteu reagent as described by [54]. One milliliter of sample (1000 $\mu \mathrm{g}$ in $1 \mathrm{~mL})$ was added to $5 \mathrm{~mL}$ of Folin-Ciocalteu reagent (diluted with water 1:10, v/v) and $4 \mathrm{~mL}$ sodium carbonate $(75 \mathrm{~g} / \mathrm{L})$. The tubes were vortex mixed for $15 \mathrm{~s}$ and left stand $30 \mathrm{~min}$ at $40{ }^{\circ} \mathrm{C}$, before measuring the absorbance of the developed color at $765 \mathrm{~nm}$. Gallic acid was used to establish the standard curve (20-200 $\mu \mathrm{g} / \mathrm{mL})$. The extent of reducing of the Folin-Ciocalteu reagent by the sample was expressed as mg of gallic acid equivalents (GAE) per $g$ of extract. The calibration equation for gallic acid was $y=0.001 x+0.0563\left(R^{2}=0.9792\right)$, where $y$ and $x$ are the absorbance and concentration of gallic acid in $\mu \mathrm{g} / \mathrm{mL}$, respectively.

\subsubsection{Total Flavonoids (TFs) Determination}

Total flavonoids (TFs) were estimated according to the protocol of [55] by blending $2 \mathrm{~mL}$ aliquot of $20 \mathrm{~g} / \mathrm{L} \mathrm{AlCl}_{3}$ ethanol reagent with $1 \mathrm{~mL}$ of the extract (1000 $\mu \mathrm{g}$ in $1 \mathrm{~mL}$ solvent) and measuring the developed color absorbance at $420 \mathrm{~nm}$ after $60 \mathrm{~min}$. Quercetin was used to establish the standard curve $(20-200 \mu \mathrm{g} / \mathrm{mL})$ and total flavonoid content was expressed as quercetin equivalent $(\mathrm{QE})$, based on the standard curve. The calibration equation for quercetin was $y=0.0012 x+0.008\left(R^{2}=0.944\right)$, where $y$ is absorbance and $x$ is concentration of quercetin in $\mu \mathrm{g} / \mathrm{mL}$.

\subsubsection{Gas Chromatography-Mass Spectrometry (GC-MS) Analysis}

The chemical composition analysis of the samples was carried out using Trace GC1310-ISQ mass spectrometer (Thermo Scientific, Austin, TX, USA) with a direct capillary column TGram negative5MS (30 $\mathrm{mm} \times 0.25 \mathrm{~mm} \times 0.25 \mu \mathrm{m}$ film thickness, Thermo Scientific, Austin, TX, USA). The column oven 
temperature was initially held at $50{ }^{\circ} \mathrm{C}$; then increased by $7{ }^{\circ} \mathrm{C} / \mathrm{min}$ increments to $200{ }^{\circ} \mathrm{C}$ hold for $2 \mathrm{~min}$; and the final temperature at $290^{\circ} \mathrm{C}$ was reached by $15^{\circ} \mathrm{C} / \mathrm{min}$ increments and held for $2 \mathrm{~min}$. The injector and MS transfer line temperatures were kept at 270 and $250{ }^{\circ} \mathrm{C}$, respectively. Helium, the carrier gas, was pumped at a constant flow rate of $1 \mathrm{~mL} / \mathrm{min}$. The solvent delay was $3 \mathrm{~min}$, and $1 \mu \mathrm{L}$ aliquots of the diluted samples were injected automatically using an Autosampler AS1300 coupled (Thermo Scientific, Austin, TX, USA) with GC. The ion source temperature was set at $200{ }^{\circ} \mathrm{C}$. EI mass spectra were collected at $70 \mathrm{eV}$ ionization voltages over a range of $m / z 45-400$ within full scan mode. The chemical composition of the obtained components was concluded by comparing their retention times and mass spectra with those of WILEY 09 and NIST 11 mass spectral database.

\subsection{Collection of Pathogenic Bacteria and Fungi}

S. aureus DSM 1104, St. pyogenes ATCC 19615, L. monocytogenes LMG10470, E. coli LMG 8223, K. pneumonia ATCC 43816 and P. aeruginosa LMG 8029 were used. Also, pathogenic fungi such as A. ochraceus EMCC516 were obtained from Egyptian Microbial Culture Collection (Microbiological Resoures Center MIRCEN, Cairo, Egypt); other fungi were F. oxysporum, p. citrinium and P. expansum. All bacteria and fungi used in this study were kindly offered by Botany and Microbiology Department (Laboratory of Bacteriology and Laboratory of fungi), Faculty of Science, Zagazig University, Zagazig, Egypt. Stock bacterial cultures were routinely kept at $-20{ }^{\circ} \mathrm{C}$ in glass beads and were sub-cultured and propagated in brain heart infusion broth (BHIB) (Oxoid). Slope cultures were prepared fresh on nutrient agar for every experiment [11] and stored at $4{ }^{\circ} \mathrm{C}$ throughout the experimental work.

\subsection{Antibacterial and Antifungal Activities of the CPRES}

The antibacterial and antifungal activities of CPREs $(2000 \mu \mathrm{g} / \mathrm{mL})$ were tested against the experimental pathogenic bacteria and fungi by agar well-diffusion assays [56].

\subsection{MIC Values of H. Sabdariffa CPRE}

Pure cultures of bacterial strains were sub-cultured on BHIB at $37^{\circ} \mathrm{C}$. Each strain was spread uniformly onto an individual plate with a sterile cotton swab. Uniform wells (6 mm diameters) were made on nutrient agar (NA) plates using a gel puncturing tool. Aliquots $(50 \mu \mathrm{L})$ of pigment solutions $(0,25,50,100,200$ and $250 \mu \mathrm{g} / \mathrm{mL})$ were placed into each well. Sterilized distilled water was considered the negative control. After $24 \mathrm{~h}$ incubation at $37^{\circ} \mathrm{C}$, the diameters of the inhibition zones (mm) were measured using a transparent millimeter ruler. The pure cultures of fungal strains were sub-cultured on yeast extract agar (YES) at $30^{\circ} \mathrm{C}$. Each strain was spread uniformly onto the individual plates using sterile cotton swabs. Wells of $6 \mathrm{~mm}$ diameter were similarly made on YES plates. Aliquots $(50 \mu \mathrm{L})$ of HCPRE and B. oleracea pigment solutions $(0,100,200,300,400$ and $500 \mu \mathrm{g} / \mathrm{mL})$ were placed in each well. After 4 days' incubation at $30^{\circ} \mathrm{C}$, the diameters of inhibition zones (mm) were similarly measured.

\subsection{Quantitative Inhibition of Pathogenic Bacteria by CPRE (Bacterial Growth Curve)}

A series of test tubes each containing $10 \mathrm{~mL}$ of nutrient broth (NB) were inoculated with $100 \mu \mathrm{L}$ of $\log$ phase bacterial suspension and were then treated with $50 \mu \mathrm{g} / \mathrm{mL}$ HCPRE for all bacteria; and $200 \mu \mathrm{g} / \mathrm{mL}$ B. oleracea pigment for E. coli and $100 \mu \mathrm{g} / \mathrm{mL}$ for other bacteria. Control test tubes contained NB with bacteria only. Samples and controls were incubated at $37^{\circ} \mathrm{C}$. Growth was determined at time 0 and after $6,12,18,24,30,36,42$ and $48 \mathrm{~h}$ of incubation by the turbidity method (OD600) using a spectrophotometer (JENWAY-6405 UV/VIS, Chelmsford, England).

\subsection{Scanning and Transmission Electron Microscopy (SEM-TEM)}

S. aureus (Gram positive bacteria) and K. pneumonia (Gram negative bacteria) were selected for scanning electron microscopy (SEM) and transmission electron microscopy (TEM). Bacteria were grown on NB media and incubated at $37^{\circ} \mathrm{C}$ to reach maximum level of $10^{6} \mathrm{CFU} / \mathrm{mL}$. The MIC values 
of about $50 \mu \mathrm{g} / \mathrm{mL}$ of HCPRE were added to S. aureus and K. pneumonia plates except for controls and incubated at $37^{\circ} \mathrm{C}$ for $18 \mathrm{~h}$. Also A. ochraceus was grown on YSA and incubated at $30^{\circ} \mathrm{C}$ for 3 days to reach the maximum level of growth and MIC value of about $100 \mu \mathrm{g} / \mathrm{mL}$ of $H$. sabdariffa pigment.

\subsubsection{Scanning Electron Microscopy (SEM)}

SEM (JEOL-scanning electron microscope JSM-6510 L.V SEM-JAPAN) at electron microscope (EM) Unit, Mansoura University, Egypt was used to evaluate the morphological changes of tested microorganisms as described in $[2,16]$.

\subsubsection{Transmission Electron Microscopy (TEM)}

TEM (JEOL JEM -2100, JAPAN) at EM Unit, Mansoura University, Egypt was used to evaluate ultrastructural changes of tested microorganisms as described in [14,57].

\subsection{Statistical Analysis}

The collected data were tabulated and analyzed using IBM SPSS software (version 26, IBM corporation, Chicago, IL, USA). The results were expressed as a means \pm standard errors (SEs) in either tables or figures.

\section{Conclusions}

According to the obtained results, it can be concluded that $H$. sabdariffa pigment could be used as an antibacterial and antifungal agent. It can be efficiently and successfully used as safe, natural products. It can be prepared with low costs.

Supplementary Materials: The following are available online.

Author Contributions: M.S., G.E., A.-R.A.-M., A.I., and S.A.-S suggested the work protocol, interpreted the results and revised the manuscript. S.A.-S., A.I., A.O. and B.M. performed the laboratory experiments regarding microbiological and chemical investigations and prepared the manuscript. A.-R.A.-M. financed the publication fees.

Funding: Zagazig University, Zagazig, Egypt, supported the experimental work. A.-R.A.-M. from the Department of Science, King Khalid Military Academy, Riyadh 11495, P.O. Box 22140, Saudi Arabia, was responsible for paying the publication fees.

Acknowledgments: The authors are indebted to Zagazig University, Egypt for facilities throughout the experimental work, and thank Samer Teleb, Taxonomy and Flora, Botany and Microbiology Department, Faculty of Science, Zagazig University, Egypt for the botanical classification of the plants. Also, thanks A. H. Moustafa for his help in GC-MS analysis.

Conflicts of Interest: The authors declare no conflict of interest.

\section{References}

1. Laxminarayan, R.; Duse, A.; Wattal, C.; Zaidi, A.K.; Wertheim, H.F.; Sumpradit, N.; Vlieghe, E.; Hara, G.L.; Gould, I.M.; Goossens, H. Antibiotic resistance-The need for global solutions. Lancet Infect. Dis. 2013, 13, 1057-1098. [CrossRef]

2. Sitohy, M.Z.; Mahgoub, S.A.; Osman, A.O. In vitro and in situ antimicrobial action and mechanism of glycinin and its basic subunit. Int. J. Food Microbiol. 2012, 154, 19-29. [CrossRef] [PubMed]

3. Osman, A.; Goda, H.A.; Abdel-Hamid, M.; Badran, S.M.; Otte, J. Antibacterial peptides generated by Alcalase hydrolysis of goat whey. LWT-Food Sci. Technol. 2016, 65, 480-486. [CrossRef]

4. Sitohy, M.; Osman, A. Antimicrobial activity of native and esterified legume proteins against Gram-negative and Gram-positive bacteria. Food Chem. 2010, 120, 66-73. [CrossRef]

5. Abdel-Hamid, M.; Goda, H.A.; De Gobba, C.; Jenssen, H.; Osman, A. Antibacterial activity of papain hydrolysed camel whey and its fractions. Int. Dairy J. 2016, 61, 91-98. [CrossRef]

6. Osman, A.O.; Mahgoub, S.A.; Sitohy, M.Z. Preservative action of $11 S$ (glycinin) and 7S ( $\beta$-conglycinin) soy globulin on bovine raw milk stored either at 4 or $25^{\circ} \mathrm{C}$. J. Dairy Res. 2013, 80, 174-183. [CrossRef] [PubMed] 
7. Mahgoub, S.; Osman, A.; Sitohy, M. Inhibition of growth of pathogenic bacteria in raw milk by legume protein esters. J. Food Prot. 2011, 74, 1475-1481. [CrossRef]

8. Sitohy, M.; Mahgoub, S.; Osman, A.; El-Masry, R.; Al-Gaby, A. Extent and mode of action of cationic legume proteins against Listeria monocytogenes and Salmonella Enteritidis. Probiotics Antimicrob. Proteins 2013, 5, 195-205. [CrossRef]

9. Sitohy, M.; Mahgoub, S.; Osman, A. Controlling psychrotrophic bacteria in raw buffalo milk preserved at $4 \mathrm{C}$ with esterified legume proteins. LWT-Food Sci. Technol. 2011, 44, 1697-1702. [CrossRef]

10. Mahgoub, S.A.; Sitohy, M.Z.; Osman, A.O. Counteracting recontamination of pasteurized milk by methylated soybean protein. Food Bioprocess Technol. 2013, 6, 101-109. [CrossRef]

11. Abdel-Shafi, S.; Osman, A.; Enan, G.; El-Nemer, M.; Sitohy, M. Antibacterial activity of methylated egg white proteins against pathogenic Gram positive and Gram negative bacteria matching antibiotics. SpringerPlus 2016, 5, 983. [CrossRef] [PubMed]

12. Sitohy, M.Z.; Osman, A.O. Enhancing milk preservation with esterified legume proteins. Probiotics Antimicrob. Proteins 2011, 3, 48-56. [CrossRef] [PubMed]

13. Osman, A.; El-Araby, G.M.; Taha, H. Potential use as a bio-preservative from lupin protein hydrolysate generated by alcalase in food system. J. Appl. Biol. Biotechnol. 2016, 4, 76-81.

14. Abdel-Shafi, S.; Al-Mohammadi, A.-R.; Osman, A.; Enan, G.; Abdel-Hameid, S.; Sitohy, M. Characterization and Antibacterial Activity of 7S and 11S Globulins Isolated from Cowpea Seed Protein. Molecules 2019, 24, 1082. [CrossRef] [PubMed]

15. Mahgoub, S.A.; Osman, A.O.; Sitohy, M.Z. Impeding Bacillus spore germination in vitro and in milk by soy glycinin during long cold storage. J. Gen. Appl. Microbiol. 2016, 62, 52-59. [CrossRef]

16. Osman, A.; Daidamony, G.; Sitohy, M.; Khalifa, M.; Enan, G. Soybean glycinin basic subunit inhibits methicillin resistant-vancomycin intermediate Staphylococcus aureus (MRSA-VISA) in vitro. Int. J. Appl. Res. Nat. Prod. 2016, 9, 17-26.

17. Delgado-Vargas, F.; Paredes-Lopez, O. Natural Colorants for Food and Nutraceutical Uses; CRC Press: Boca Raton, FL, USA; London, UK; New York, NY, USA; Washington, DC, USA, 2002.

18. Delgado-Vargas, F.; Jiménez, A.; Paredes-López, O. Natural pigments: carotenoids, anthocyanins, and betalains-characteristics, biosynthesis, processing, and stability. Critical Rev. Food Sci. Nutr. 2000, 40, 173-289. [CrossRef]

19. Lila, M.A. Anthocyanins and human health: an in vitro investigative approach. BioMed. Res. Int. 2004, 2004, 306-313. [CrossRef]

20. Kumar, A.; Premoli, M.; Aria, F.; Bonini, S.A.; Maccarinelli, G.; Gianoncelli, A.; Memo, M.; Mastinu, A. Cannabimimetic plants: are they new cannabinoidergic modulators? Planta 2019, 249, 1681-1694. [CrossRef]

21. Eder, R. Pigments. In Food Analysis by HPLC; Nollet, L.M., Ed.; Marcel Dekker: Monticello, NY, USA, 2000; pp. 825-880.

22. Cissé, M.; Vaillant, F.; Pallet, D.; Dornier, M. Selecting ultrafiltration and nanofiltration membranes to concentrate anthocyanins from roselle extract (Hibiscus sabdariffa L.). Food Res. Int. 2011, 44, 2607-2614. [CrossRef]

23. Diessana, A.; Parkouda, C.; Cissé, M.; Diawara, B.; Dicko, M.H. Optimization of aqueous extraction of anthocyanins from Hibiscus sabdariffa L. calyces for food application. Food Sci. Qual. Manage. 2015, 45, 23-31.

24. Saed-Moucheshi, A.; Shekoofa, A.; Pessarakli, M. Reactive oxygen species (ROS) generation and detoxifying in plants. J. Plant Nutr. 2014, 37, 1573-1585. [CrossRef]

25. Miguel, M.G. Anthocyanins: Antioxidant and/or anti-inflammatory activities. J. Appl. Pharm. Sci. 2011, 1, 7-15.

26. Mastinu, A.; Kumar, A.; Maccarinelli, G.; Bonini, S.A.; Premoli, M.; Aria, F.; Gianoncelli, A.; Memo, M. Zeolite clinoptilolite: Therapeutic virtues of an ancient mineral. Molecules 2019, 24, 1517. [CrossRef] [PubMed]

27. Elmanama, A.A.; Alyazji, A.A.; Abu-Gheneima, N. Antibacterial, antifungal and synergistic effect of Lawsonia inermis, Punica granatum and Hibiscus sabdariffa. Ann. Alquds Med. 2011, 7, 33-41.

28. Fullerton, M.; Khatiwada, J.; Johnson, J.U.; Davis, S.; Williams, L.L. Determination of antimicrobial activity of sorrel (Hibiscus sabdariffa) on Esherichia coli O157, H7 isolated from food, veterinary, and clinical samples. J. Med. Food 2011, 14, 950-956. [CrossRef] [PubMed] 
29. Cartea, M.E.; Francisco, M.; Soengas, P.; Velasco, P. Phenolic compounds in Brassica vegetables. Molecules 2011, 16, 251-280. [CrossRef]

30. Ahmadiani, N.; Robbins, R.J.; Collins, T.M.; Giusti, M.M. Anthocyanins contents, profiles, and color characteristics of red cabbage extracts from different cultivars and maturity stages. J. Agric. Food Chem. 2014, 62, 7524-7531. [CrossRef]

31. Xu, Z.; Wu, J.; Zhang, Y.; Hu, X.; Liao, X.; Wang, Z. Extraction of anthocyanins from red cabbage using high pressure CO2. Bioresour. Technol. 2010, 101, 7151-7157. [CrossRef]

32. Isabelle, M.; Lee, B.L.; Lim, M.T.; Koh, W.-P.; Huang, D.; Ong, C.N. Antioxidant activity and profiles of common vegetables in Singapore. Food Chem. 2010, 120, 993-1003. [CrossRef]

33. Wiczkowski, W.; Szawara-Nowak, D.; Topolska, J. Red cabbage anthocyanins: Profile, isolation, identification, and antioxidant activity. Food Res. Int. 2013, 51, 303-309. [CrossRef]

34. Kapusta-Duch, J.; Kopec, A.; Piatkowska, E.; Borczak, B.; Leszczynska, T. The beneficial effects of Brassica vegetables on human health. Rocz. Panstw. Zakl. Hig. 2012, 63, 389-395. [PubMed]

35. Osman, A.; Abd-Elaziz, S.; Salama, A.; Eita, A.A.; Sitohy, M. Health Protective Actions of Phycocyanin Obtained from an Egyptian Isolate of Spirulina platensis on Albino Rats. Eur. Asian J. BioSci. 2019, 13, 105-112.

36. Sitohy, M.; Osman, A.; Ghany, A.; Salama, A. Antibacterial phycocyanin from Anabaena oryzae SOS13. Int J. Appl. Res. Nat. Prod. 2015, 8, 27-36.

37. Salama, A.; Ghany, A.A.; Osman, A.; Sitohy, M. Maximising phycocyanin extraction from a newly identified Egyptian cyanobacteria strain: Anabaena oryzae SOS13. International Food Res. J. 2015, 22, 517.

38. Khan, M.I. Plant betalains: Safety, antioxidant activity, clinical efficacy, and bioavailability. Compr. Rev Food Sci. Food Saf. 2016, 15, 316-330. [CrossRef]

39. Wu, L.-C.; Hsu, H.-W.; Chen, Y.-C.; Chiu, C.-C.; Lin, Y.-I.; Ho, J.-A. Antioxidant and antiproliferative activities of red pitaya. Food Chem. 2006, 95, 319-327. [CrossRef]

40. Adam Burrows, J.D. Palette of our palates: A brief history of food coloring and its regulation. Compr. Rev. Food Sci. Food Saf. 2009, 8, 394-408. [CrossRef]

41. Chaitanya Lakshmi, G. Food coloring: The natural way. Res. J. Chem. Sci. 2014, 2231, 606X.

42. Ouyang-Latimer, J.; Jafri, S.; VanTassel, A.; Jiang, Z.-D.; Gurleen, K.; Rodriguez, S.; Nandy, R.K.; Ramamurthy, T.; Chatterjee, S.; McKenzie, R. In vitro antimicrobial susceptibility of bacterial enteropathogens isolated from international travelers to Mexico, Guatemala, and India from 2006 to 2008. Antimicrob. Agents Chemother. 2011, 55, 874-878. [CrossRef]

43. Iwu, M.W.; Duncan, A.R.; Okunji, C.O. New antimicrobials of plant origin. In Perspectives on New Crops and New Uses; ASHS Press: Alexandria, VA, USA, 1999; pp. 457-462.

44. Giuliani, A.; Rinaldi, A.C. Beyond natural antimicrobial peptides: multimeric peptides and other peptidomimetic approaches. Cell. Mol. Life Sci. 2011, 68, 2255-2266. [CrossRef] [PubMed]

45. Riaz, G.; Chopra, R. A review on phytochemistry and therapeutic uses of Hibiscus sabdariffa L. Biomed. Pharm. 2018, 102, 575-586. [CrossRef] [PubMed]

46. Wang, L.-S.; Stoner, G.D. Anthocyanins and their role in cancer prevention. Cancer Lett. 2008, 269, $281-290$. [CrossRef] [PubMed]

47. Chao, C.-Y.; Yin, M.-C. Antibacterial effects of roselle calyx extracts and protocatechuic acid in ground beef and apple juice. Foodborne Pathog. Dis. 2009, 6, 201-206. [CrossRef] [PubMed]

48. Abou-Arab, A.A.; Abu-Salem, F.M.; Abou-Arab, E.A. Physico-chemical properties of natural pigments (anthocyanin) extracted from Roselle calyces (Hibiscus subdariffa). J. Am. Sci. 2011, 7, 445-456.

49. Vasudeva, N.; Sharma, S. Biologically Active Compounds from the Genus Hibiscus. Pharm. Biol. 2008, 46, 145-153. [CrossRef]

50. Singh, P.; Khan, M.; Hailemariam, H. Nutritional and health importance of Hibiscus sabdariffa: a review and indication for research needs. J. Nutr. Health Food Eng. 2017, 6, 00212.

51. Silva, S.; Costa, E.M.; Mendes, M.; Morais, R.; Calhau, C.; Pintado, M. Antimicrobial, antiadhesive and antibiofilm activity of an ethanolic, anthocyanin-rich blueberry extract purified by solid phase extraction. J. Appl. Microbiol. 2016, 121, 693-703. [CrossRef]

52. Siva, R.; Palackan, M.G.; Maimoon, L.; Geetha, T.; Bhakta, D.; Balamurugan, P.; Rajanarayanan, S. Evaluation of antibacterial, antifungal, and antioxidant properties of some food dyes. Food Sci. Biotechnol. 2011, 20, 7-13. [CrossRef] 
53. Paśko, P.; Bartoń, H.; Zagrodzki, P.; Gorinstein, S.; Fołta, M.; Zachwieja, Z. Anthocyanins, total polyphenols and antioxidant activity in amaranth and quinoa seeds and sprouts during their growth. Food Chem. 2009, 115, 994-998. [CrossRef]

54. Waterhouse, A.L. Determination of total phenolics. Curr. protoc. Food Anal. Chem. 2002, 6, I1.1.1-I1.1.8.

55. Adebiyi, O.E.; Olayemi, F.O.; Ning-Hua, T.; Guang-Zhi, Z. In vitro antioxidant activity, total phenolic and flavonoid contents of ethanol extract of stem and leaf of Grewia carpinifolia. Beni-Suef Univer. J. Basic Appl. Sci. 2017, 6, 10-14. [CrossRef]

56. Nanda, A.; Saravanan, M. Biosynthesis of silver nanoparticles from Staphylococcus aureus and its antimicrobial activity against MRSA and MRSE. Nanomed. Nanotechnol. Biol. Med. 2009, 5, 452-456. [CrossRef] [PubMed]

57. Abdel-Shafi, S.; Osman, A.; Al-Mohammadi, A.-R.; Enan, G.; Kamal, N.; Sitohy, M. Biochemical, biological characteristics and antibacterial activity of glycoprotein extracted from the epidermal mucus of African catfish (Clarias gariepinus). Int. J. Biol. Macromol. 2019, 138, 773-780. [CrossRef] [PubMed]

Sample Availability: Samples of the compounds are not available from the authors.

(C) 2019 by the authors. Licensee MDPI, Basel, Switzerland. This article is an open access article distributed under the terms and conditions of the Creative Commons Attribution (CC BY) license (http://creativecommons.org/licenses/by/4.0/). 